\title{
The Sustainable Management of the City: Examples of Implementation of Agenda 21 in Spain
}

\author{
José Antonio Aldrey Vázquez* and Miguel Pazos Otón
}

\author{
Department of Geography. Faculty of Geography and History. Pza. Universidade 1, University of Santiago de \\ Compostela, Spain
}

\begin{abstract}
After the Rio Summit (1992), the European Conference on Sustainable Cities and Towns -held in Aalborg in May 1994- ended with the drawing up of the Aalborg Charter, a document signed by 80 European local administrations. This Charter set out the main principles of sustainable urban management through the Local Agenda 21 programme, with public-private agreement and citizens' participation as key principles.

The work methodology of the Local Agenda 21 is based on the drawing up of several indicators on economic, social and environmental aspects. There are increasingly more municipalities in Europe implementing Local Agendas 21 and developing them through analysis, action plan and monitoring stages. This essay studies the implementation in Spain of two of the most important issues addressed in Local Agendas 21: sustainable mobility and the recovery of degraded urban areas.
\end{abstract}

Keywords: Agenda 21, urban management, sustainability, Spain.

\section{EMERGENCE OF THE LOCAL AGENDA 21}

During the 1970's, European society in particular, but also the whole Western World, became more clearly aware that the economic growth model based on an irrational exploitation of natural resources and implemented without any environmental control could not be maintained indefinitely due to its unsustainability in the medium term, as some clear effects of environmental degradation were already evident. Thus, the need of a new development model entailing a rational management of natural resources with strict environmental control and protection instruments was recognized. However, it was not until the late 1980's that the concept of sustainable development spread, first appearing officially in the Brundtland Report of the United Nations World Commission on the Environment and Development in 1987, which defined it as: "development that meets the needs of the present without compromising the ability of future generations to meet their own needs".

Taking this new concept as a starting point, there was an attempt to adopt a new alternative development model, which became a reality in the United Nations Conference on Environment and Development, better known as the Earth Summit, held in Rio de Janeiro in 1992. The Programme 21 came out of this summit. It was a comprehensive document which committed its signatories to boost sustainable development through the concepts of respect for the environment, social equity and durability [1].

The Local Agenda 21 (hereafter LA21) is one of the 40 chapters making up the Programme 21 -number 28- and

*Address correspondence to this author at the Department of Geography. Faculty of Geography and History. Pza. Universidade 1, University of Santiago de Compostela, Spain; Tel: +34 981 563100, Ext. 12545; Fax: +34 981 599935; E-mail: joseantonio.aldrey@usc.es follows the principles of the latter, as its goals are to promote social justice, a sustainable economy and a long-lasting environment to achieve a sustainable balance that leads to a better quality of life [2].

The subsidiarity principle underlies the LA21, proposing a decentralized development which is close to citizens and based on social participation both in its design and implementation, but also agreed on, where every town or municipality must be able to organize itself and to set up action plans and management models [3]. At the same time, such local policies should not act in isolation from each other; they should rather be consistent with those governing at higher administrative levels [4]. Therefore, the LA21 aims at developing an Action Plan to face the challenge of sustainability by combining governmental policies with the specific actions of the civil society.

The LA21 was promoted by the International Council for Local Environmental Iniciatives (ICLEI), the internacional organization which has made the most effort to boost it. The ICLEI, as commissioned by the European Commission, organized the First Conference of Sustainable Cities and Towns, held in Aalborg in 1994, where the Aalborg Charter Charter of European Cities \& Towns Towards Sustainability- was adopted. This Charter was first signed by 80 cities and towns and it has been signed and supported by every European local administration which decided to start implementing a LA2 1 since then. The ICLEI has also made the effort to draw up a methodological guide for designing and implementing LA21s [5] a vital grounding for local bodies to start working with a few common criteria.

Later, four more conferences were held (Lisbon, 1996; Hannover, 2000; Aalborg + 10, 2004; and Seville, 2007) where the principles and values for sustainable local actions were defined exactly and the responsibility of municipalities towards them was emphasized. On the tenth aniversary of 
the first conference a new document called The Aalborg Commitments set out a total of ten commitments: governance, local management towards sustainability, natural common goods, responsible consumption and lifestyle choices, planning and design, better mobility and less traffic, local action for health, vibrant and sustainable local economy, social equity and justice, and local to global.

LA21 can therefore be defined as an action plan for designing strategies of intervention on a local scale to fulfil the existing ten principles. In order to carry out such interventions, the problems of environmental unsustainability must be first identified by means of an environmental audit in each city or town, so that later those strategies can be implemented on the basis of a new model of co-operation between public administrations and social and economic stakeholders.

In Europe, the implementation of the LA21 has been inconsistent both territorially and over time. The governing autonomy of local bodies and the consolidation of experiences in environmental policy prior to the 1992 Earth Summit have been vital for a rapid initial introduction. The degree of commitment of the government of each country and the dynamism of local institutions and social and economic stakeholders have been of great significance as well.

The first countries to start introducing LA21s were Sweden, the Netherlands, Denmark and the United Kingdom. Sweden is an ideal case as all of its municipalities have some plan to put the LA21 into effect. Apart from the aforementioned counties, also Germany, Finland and Norway have great experience in such implementation. Except for the United Kingdom -where the implementation of these initiatives was strongly linked to the leading role of ecology associations in promoting the concept of sustainable development- the other countries mentioned before are territories with local entities having a high authority quota and an established concern for implementing strict environmental policies [6].

The rest of European countries have gone through a far slower LA21 implementation process. But some of them such as Spain or Italy- have implemented the LA21 in a massive way, thus becoming the two countries with the most municipal entities to have supported the Aalborg Charter (38 and $36 \%$ respectively out of the total of European signing towns in 2004). We will look at the LA21 introduction process in Spain below.

\section{THE LOCAL AGENDA 21 IN SPAIN}

Spain has experienced a strong implementation process in recent years, with very significant numbers, as 60 municipal councils had signed the Aalborg Charter in 1998 and in 2006 over 900 cities and towns had already committed themselves to adopt such plans. In almost every case there had been virtually no pre-existing municipal sustainability policies [3].

In Spain, the central Government has practically kept out of LA21s as this matter is deemed to be out of its competence. It may also be said that the late launch of this initiative was mainly due to the fact that at first only a few regional administrations gave impetus to LA21 processes - especially Catalonia, the Basque Country, Andalusia and Valencia. However, most of them have joined strongly after that and now play a central role in fostering the LA2 1 introduction together with provincial councils administrative entities which manage services and equipments at provincial level. Nowadays, most governments of the Spanish Autonomous Communities give incentives to town councils for implementing the programme, often complemented with technical and methodological support.

Even the regional governments of Navarra and Catalonia have carried out their own LA21 implementation plans for the whole of their territory. At the same time, some Autonomous Communities have either not adopted any initiative or have done it to give a political image of concern for the environment -Aragón, La Rioja, Asturias, Cantabria and Extremadura-, which does not mean that the town councils of those territories progress significantly on their own in the implementation of LA21s.

In Autonomous Communities, LA21 programmes are usually assigned to regional ministries of environment, with Catalonia being the only exception -the Ministry of the Presidency is responsible. It is not unusual for other regional ministries to co-operate in specific tasks or for there to be associations, foundations or entities devoted to their implementation, as it happens with FIDA in Madrid, DEYNA in Castille and León, or IHOBE in the Basque Country [3]. Town council networks and partnerships created for sustainable development are also extremely important - the Xarxa de Municipis in Catalonia, backed by the provincial council; or RECSA in Andalusia-, as well as the Federations of Town Councils and Provinces -state town council association with local offices which safeguards the competences and rights of local administrations-, which play a vital role in putting into contact the different municipal entities and in fostering information exchange between them [1].

On the other hand, Autonomous Communities work to prepare methodological material for supporting and facilitating local technicians' work on implementing LA21s, also promoting environmental training by organizing many courses and conferences especially intended to local agents involved in the implementation of sustainable development programmes. One of the most widely used methodologies initially devised by the Provincial Council of Barcelona and then adapted to town councils in the whole of Spain- is based on four stages, the development of which took place after town councils joined the Aalborg Charter [7]. The first stage entails producing general information about the town council. The second stage involves making a diagnosis and analysis of the current environmental situation. The third stage is about drawing up an Environmental Action Plan by setting out strategic lines and defining actions, as well as an audit document. Finally, the fourth stage is the post-audit and monitoring stage.

Although the theoretical approach of LA21s is unquestionably positive, we should make a critical assessment of its introduction in Spain, as failures have been common in many launched initiatives. The lack of success has been accompanied by mistakes in environmental diagnosis, in implementing action plans and in decision- 
making processes. In other cases, the distortion of the programme has been brought about by the non-binding character of proposals, which are left as simple politically correct and clean-up statements for citizens. This situation has also been fostered by the loss of the subsidiarity sense with which such programmes were born, thus becoming the expression of leading local political groups without citizens' involvement - except for very few cases- in the LA21 design and implementation process [1].

From a methodological point of view, the arbitrary choice of sustainability indicators and the lack of transversality have also led to proposals which had not been given enough thought and which are far removed from the concept of sustainable development, forgetting the essential principles of integration of social, economic and environmental issues.

However, it should be also pointed out that there have been really successful LA21s with a strong and well articulated involvement of social, political and economic stakeholders, particularly in Catalonia, the Balearics, Valencia and Andalusia. Some experiences of town council networks have produced very positive results as well, as they have led to a great flow of interaction initiatives, information exchange and good results, such as the Xarxa of Barcelona's Provincial Council of or in the Basque Country's town council networks.

Some specific actions in key subject fields stand out among these cases of success in implementing LA21s in Spain and these deserve to be highlighted. We have selected two aspects which we consider to be essential to achieve economic, social and environmental sustainability in cities: sustainable mobility and transport and recovery of degraded urban areas.

As for the first aspect, four cases of Spanish cities standing out as an example of good practices in mobility management -in accordance with LA21 principles- will be analyzed. As for the second aspect, we will focus on policies for the rehabilitation of urban derelict areas and set out a proposal of methodology to mainstream them in LA21s in Spain.

\section{SUSTAINABLE MOBILITY AS AN ESSENTIAL PRINCIPLE OF LA21S: EXAMPLES OF GOOD PRACTICE IN SPAIN}

Another of the most important subject fields of application of Agendas 21 has to do with sustainable mobility and transport. At the local level (scope of Agendas 21), public powers have a great responsibility to contribute to attain a modal distribution which prioritizes sustainable forms -mobility on foot, by bicycle, and by public transport in general- over other more aggressive forms, both from a social and an economic and environmental point of view [8].

These kinds of measures are currently based in the socalled Mobility Management. Mobility Management is primarly a demand oriented approach to passenger and freight transport that involves new partnerships and a set of tools to support and encourage change of attitude and behaviour towards sustainable modes of transport. These tools are usually based on information, communication, organisation, coordination and require promotion [8].
The core of Mobility Management are "soft" measures (e.g. information or coordination of existing user services), which enhance the effectiveness of "hard" measures of traffic planning (e.g. new tram lines, new roads and new bike tracks). Mobility Management tools (in comparison to "hard" measures) do not necessarily require large investments measured against their high potential to change mobility behaviour. The objective of Mobility Management is to reduce single car use.

Among all transport modes, private motorized transport is presently one of the greatest polluting agents in developed countries. Its spread to virtually the whole society and the increase of motorization indexes should urge us to reflect on the necessity to limit its use. The mass use of cars explains why developed countries cause around $25 \%$ of toxic gas emissions to the atmosphere [9].

This problem gets worse at the local level. The city is an space characterized by high demographic and commuting densities. The prevalence of a transport model based on cars has a negative impact on the urban environment, economy and society, which can be summed up as follows:

1. Emission of harmful gases. The smoke coming from fuel combustion is a clear polluting agent. CO2 and other harmful gases cause thousands of direct and indirect deaths every year and contribute to an unhealthy urban atmosphere.

2. Emission of noise. Although this factor is usually paid little attention compared to the previous one, transport obviously turns cities into a very noisy space. Car engines and horns make noise which causes physical-psychological disorders to people. Sleep disturbances, stress and less productivity are the most apparent consequences.

3. Occupation of urban spaces by cars and less quality of life for citizens. The predominance of a car-based model in cities implies that a considerable part of the urban space is occupied by roads and parking. Town planners are currently aware of how important it is to recover the city for citizens. This means creating more pedestrian areas and limiting car access to cities. Cities must be a meeting space made for pedestrians rather than for cars [10].

4. Diseconomies derived from transport externalities. They become evident in the lack of economic efficiency of cars compared to other means of transport, but also in terms of time. The general and mass use of cars involves wasting not only money but also working hours and therefore productivity.

5. Emergence of social inequalities in mobility and access to transport. One of the less apparent but at the same time one of the most serious consequences of the car mobility model is the emergence of big pockets of social groups with scarce mobility. When cars became the main means of transport, public transport started to play a very secondary role and has often been paid little attention by politicians and urban planners. The varied mobility of the different social groups favours middle-aged groups and 
medium-high social and labour groups, which have more chances to progress economically and socially.

As we can see, having a transport model based on private motorized transport without developing collective means of transport contradicts the principles set out in LA21s as to the importance of sustainable mobility and transport in its three environmental, economic and social dimensions $[11,12]$.

The legislation currently in force in Spain gives town councils most authority to act in local transport and mobility. Town councils are the ones which have the ability and the legal authority to manage an urban public transport system through buses, reorganize cab services, build cycle lanes or provide the city with a series of quality pedestrian routes. Therefore, it is vital that local public powers commit themselves to the principles set out in LA21s as to transport and mobility.

This does not mean that they should not look for support and coordination on other scales and at other territorial levels which have competencies on transport systems with a clear impact at the local level. This is applicable in the case of suburban trains in big Spanish cities, or the transport consortiums which manage the different means of transport in metropolitan areas, such as Madrid, Barcelona, and Bilbao.

In spite of this, in most Spanish municipalities responsibilities for transport are held almost exclusively by town councils. That is why it is important to implement transport policies which prioritize sustainability in its three dimensions [13]. Now we are going to look at some experiences carried out in Spanish town councils which are an example of good practices in mobility and transport management.

\section{SANTIAGO DE COMPOSTELA}

Santiago de Compostela, proclaimed Heritage of the Humanity, has put an emphasis on the pedestrianization of almost its whole old town since the 1980's. In particular, the old area within the walls -where the Cathedral and most historical monuments are located- became an almost exclusively pedestrian space for the enjoyment of residents and visitors.

Although at the beginning of this process some people were against the project, especially shopkeepers and landlords of the Old Town, the city council kept looking for dialogue and understanding with the main city agents to reach a consensus as to the convenience of the project. Pedestrianization was conceived as a requirement in a city where image and tourism would play a leading role. Santiago's symbolic character as capital of Galicia and the constant year-by-year rise in visitors are facts which can be linked to the pedestrianization of the city.

During this process, the work of the town council-aware of the need of applying mobility models of other similar European cities in Santiago- was vital. Likewise, residents' associations and associations of other social groups took part in the citizens' participation process that led to the drawing up of the Special Plan for the Protection of the Historic Centre, where the traffic control measures to safeguard the Old Town appear specifically [14].
Nowadays the town council is working on the extension of such control measures of road traffic to the San Pedro district. Although it is located outside the old area within the walls, this is a traditional district which is part of the grounds of the Old Town set out in the Special Protection Plan. Its high demographic density -compared to the area within the walls- and its considerable business activity have systematically delayed the implementation of an specific mobility plan. A study is now being carried out with the aim of boosting mobility on foot and attain a peaceful coexistence of vehicles and pedestrians [15]. In recent years, difficulties in car mobility and the lack of security for citizens have become determining factors which have led to the necessity of a new approach in the municipal mobility policy. The town council is being supported by the Residents Association A Xuntanza -in the San Pedro district itself- in this process. This association was created 30 years ago to give responses for a better mobility in the district.

\section{OVIEDO}

The city of Oviedo -the capital of the Princedom of Asturias- is another of the examples of good practices in local mobility management. The Old Town stands out in the urban structure of Oviedo, as it is linked to the new town and the main business area through the emblematic Uría Street. Vehicular traffic was one of Oviedo's main problems. Being a quite dense and not especially large city, the influx of residents' and non-residents' cars was constant, causing big traffic jams in the city centre. It should be taken into account that -as in the case of Santiago de Compostela- Oviedo is the capital of an Autonomous Community, with the subsequent creation and attraction of trips.

In order to recover the city for citizens, Oviedo's town council decided to pedestrianize not only the Old Town, but also the main business streets around Uría Street during the 90's. Oviedo's is one of the latests pedestrianizations in Spain, but its magnitude and the importance does not have any comparison [16]. In Oviedo, the whole of the old part of the city was closed to the traffic. But as well as the pedestrianization of an important part of the old districts, there was a prolongation of these policies in another streets and squares located out of the complete-pedestrian precinct. In these streets, the pavements have been extended, and trees have been planted, in order to improve the quality of urban environment.

These measures soon revealed to be successful and have produced many good results: comfort in trips, reinforcement of the business role of the centre and improvement of the city urban image. Uría Street was left as the main restructuring axis of public transport -buses and cabs- and goods vehicles in order to ensure vehicle accessibility in the whole area. This is a strategic measure as Uría Street connects the railway station with the Old Town.

Such local measures were complemented with the decisive support of the railway as fundamental means of transport for supra-municipal mobility, not only towards adjoining municipalities but also with the area called Ciudad Astur -including the cities of Avilés and Gijón-, where a total of a million people live in less than $40 \mathrm{~km}$ around Oviedo. Fig. (1) shows the renewed rail station in Oviedo, strategic node of the transport network in the area. 


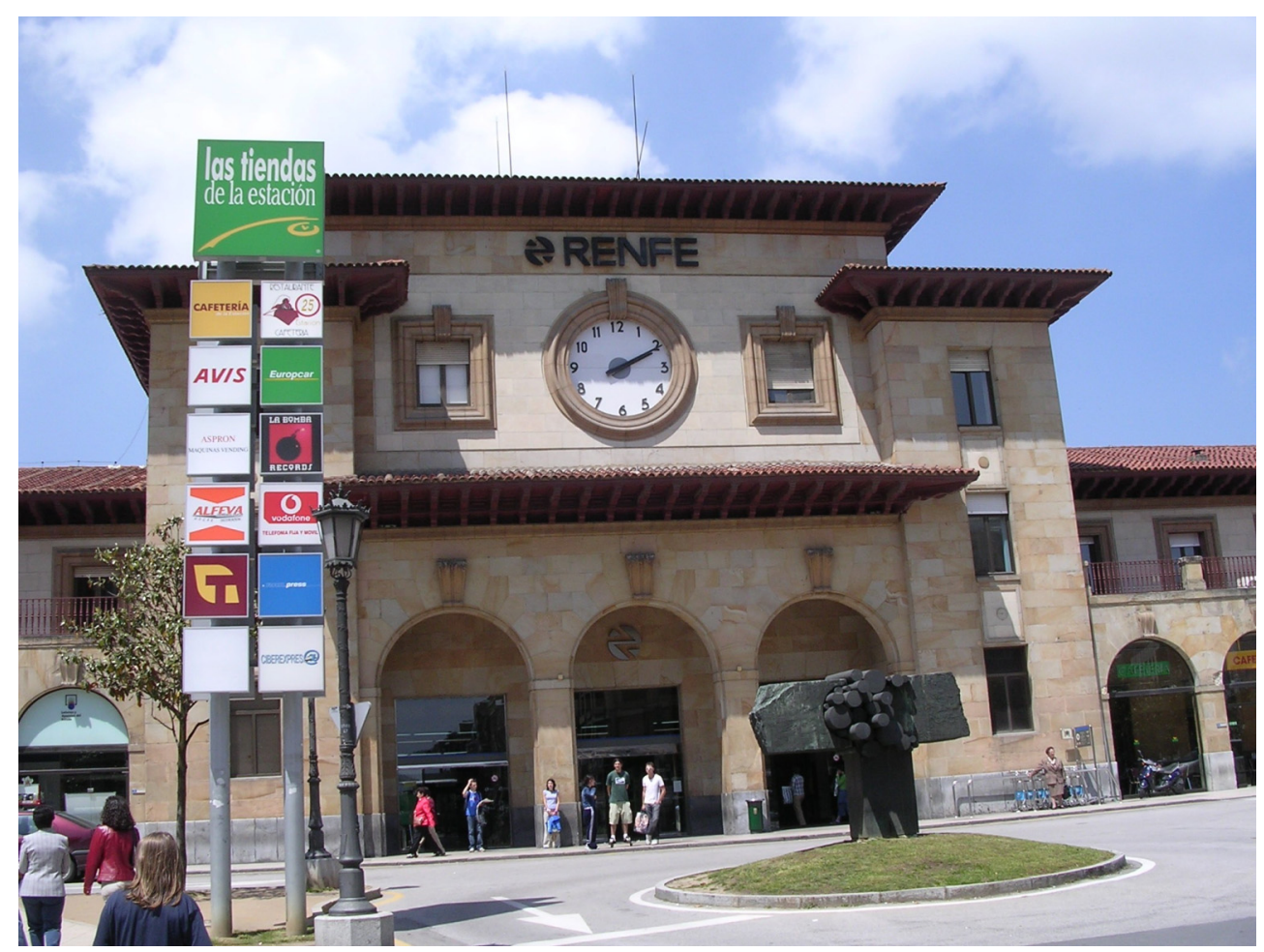

Fig. (1). The renewed rail station in Oviedo. Source: self-made.

\section{GRANADA}

The city of Granada, in southern Spain, is home to the Alhambra, one of the most visited monuments in the world, and -as Santiago de Compostela- was declared Heritage of the Humanity. Its topography is a clear determinant of mobility, as the historical area of the city is characterized by being very uneven and having steep slopes. This is particularly so in the Albayzín district, with a strong Arab influence and alleys forming complicated labyrinths, which together with the incline- makes mobility difficult. On the other hand, another of the big points which creates mobility, the Alhambra, is located in other topographically high area and separated from the former by a river bed -the banks of the Darro. Considering that both the Alhambra and the Albayzín district are two of the main sightseeing points of the city, it can be understood why it is difficult to manage tourist flows between them, especially in the summer. To the difficulty posed by the volume of flows, one should add the characteristics of roads, scarcely suitable for the present traffic. Two are the main problems that the town council faced: the impossibility of bus traffic and the lack of parking space.

Taking these premises into account, work was done with an innovative solution: limiting cars as much as possible and also boosting public transport as an incentive to leave the car home. In order to do this, a minibus system -with 20 seats each- was devised to link the two main mobility points in Granada (Fig. 2). Behind this service there is a thorough and detailed study of urban mobility, which proposed the route and frequency of the main minibus lines. Among them stands out the line linking the Alhambra and Albayzín -past España Square-, the star of Granada's transport system.
These policies were complemented with a non-usual measure in medium-sized cities in Spain: the creation of the Granada Transport Consortium. This is a Metropolitan Transport Autorithy, created in order to create and manage infrastructures and transport services in the Metropolitan Area of Granada.

The Metropolitan Transport Authority of Granada is constituted by the Regional Government, the Provincial Government and different municipalities, classified in 3 different zones. The Authority aims to finish the Intermodal Transports Plan of the Metropolitan Area of Granada, seeking the co-ordination of the public transport services, and promoting them as an only "product". The Authority also is responsible to fix the fare structure for the different transport services in the Granada Area.

The creation of the Authority is very important for the promotion of public transport and its contribution to reduce the number of car-based trips. As in all the cities with similar characteristics, one important part of the daily trips to the city center are made by commuters coming from another municipalities. In the case of Granada, the Authority has been working to promote public transport services, and thus promoting the pedestrianization in the old part of the city.

\section{TOLEDO}

Mobility in Toledo is made more difficult by its relief. With a city located on a hill, in a meander of the Tagus, the Old Town seems a destination of multiple flows due to residents and tourists' compulsory and non-compulsory trips [17]. It was precisely tourist flows what caused serious traffic jams and hindered urban mobility. Toledo is a compulsory sightseeing destination from Madrid -an hour away by motorway- and a favourite destination for tours, which use the coach as a means of transport. Before 


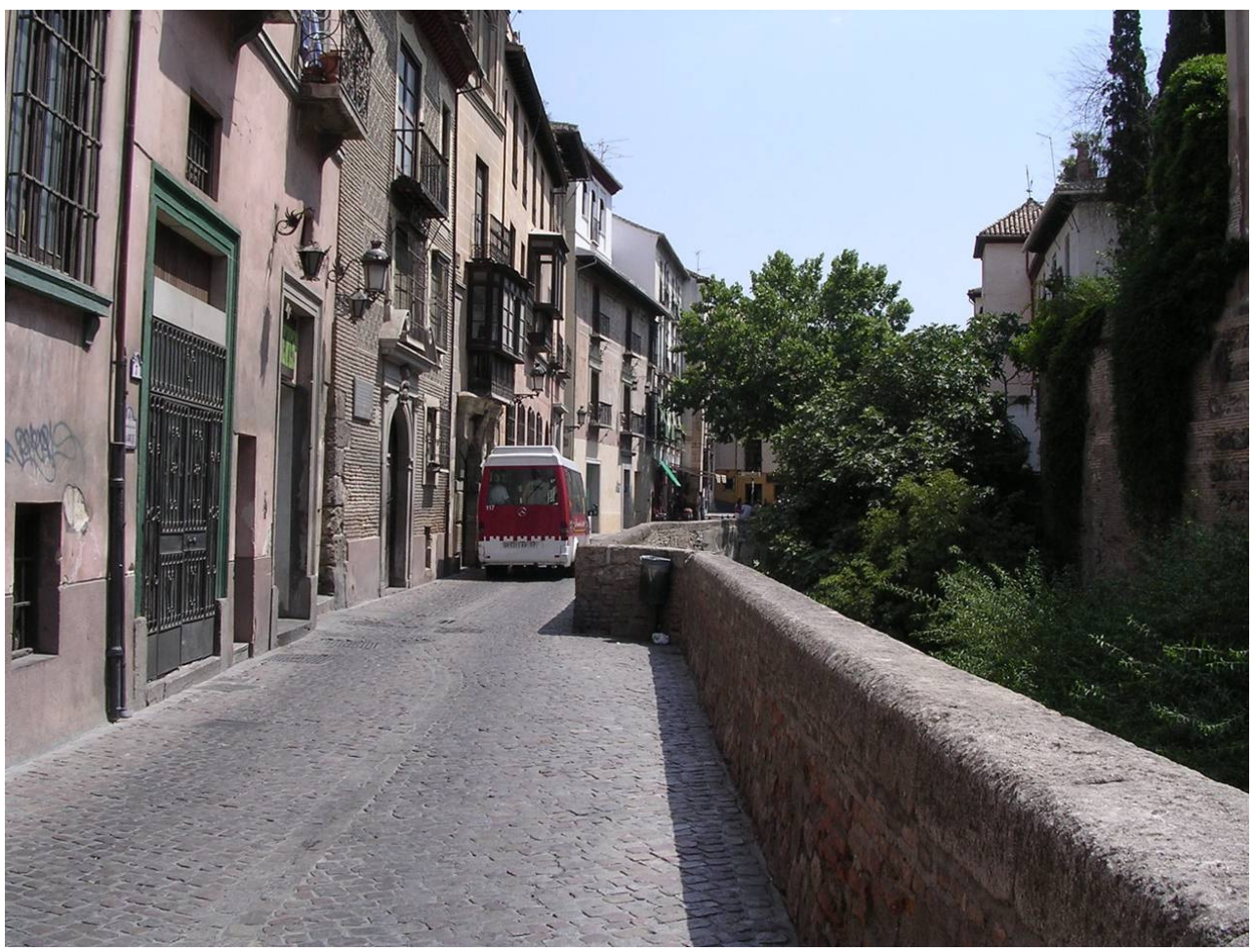

Fig. (2). Mini bus passing through the Ribera del Darro (Granada). Source: self-made.

measures to rearrange urban mobility were adopted, buses went into the historic centre and created serious conflicts with local road traffic and pedestrians. The situation was always worsened by the topographical location of the city itself, which developed into an increasingly unsustainable vicious circle.

As a result of a mobility plan commissioned to Bernhard Winkler, a decision was made to undertake an ambitious work in order to solve the problem. The technical solution involved making better use of an esplanade located by the meadow for bus parking and connecting it directly with the old town through a system of escalators. Using this system now allows a rapid pedestrian passage of tourists from the bus to the old town with the least impact. This measure was followed by others such as traffic restriction or alleviation in several parts of the city.

\section{PHYSICAL, SOCIAL AND FUNCTIONAL DISTRICT REHABILITATION: TOWARDS SUSTAINABLE AND EQUAL WELLBEING STANDARDS WITHIN CITIES. NOTES FOR ITS APPLICATION TO LA21S IN SPAIN}

Apart from the aforementioned issues about mobility, a consideration of issues about social and environmental rehabilitation of derelict districts within cities is essential when introducing and implementing LA21s. Such issues entail two measures: on the one hand, providing local residents with reasonable standard of well-being and environments similar to occupied by high standard economic activities or well-off classes -one of the main parameters of sustainable development set out in the Aalborg Charter as well as in the philosophy underlying LA21s.

Another aim is to alleviate the outskirts of the most dynamic areas in Spain by recovering socially degraded areas that are losing most of their population. This situation brings with it many negative externalities in the environmental, economic and social field -rise in polluting gas emissions, endless increase in the provision of water networks, drains, power line, waste collection, transport and communication networks; as well as an increasing congestion of them, rise in mobility times, more insecurity problems as security forces are not able to respond to the big urban discontinuous stain which is created, bigger social inequalities owing to the appearance of large-scale segregated spaces, etc. Thus, rehabilitating currently derelict, half-empty or bad-looking spaces within cities may help recover spaces to live and coexist, reducing and limiting the increasing loss of territory and cultural and landscape values caused by the uncontrolled and unsustainable present Spanish territorial model.

Although it has to be admitted that most LA21s drawn up in Spain include measures to improve peripheral districts in cities, to build and recover a higher number of dwellings which are accessible for unprivileged groups, as well as to redevelop degraded areas and create more green areas, it is also true that it was precisely these measures which proved the more difficult to implement. There were few or no economic and management instruments to put the measures into effect so that most urban recovery actions have been limited to central areas of cities, old towns of a high symbolic and heritage value or river façades with a high environmental and landscape impact [18, 19] while other areas with serious social, architectural and environmental problems have been forgotten or hardly dealt with.

It now seems possible to change the situation since an instrument appeared in the Public Housing Plan 2005-2008 [20] which funds full rehabilitation interventions not only in historic-artistic ensembles -as it happened before- but also in all districts which are over fifteen years old and show 
ageing, low income level, significant building deterioration and the need of general redevelopment so that they can recover habitability and environmental quality conditions similar to average city quality standards of the city they belong to. These are what that Plan calls Areas of Integrated Rehabilitation (ARI) outside historic centres. Such rehabilitation will be financed equally by the three territorial administrations existing in Spain: the central administration, the regional administration (Autonomous Communities) and the municipal administration.

Putting an ARI into effect entails public funding for rehabilitation and redevelopment in three fields:

1. Works within homes: replacement of kitchens, bathrooms, windows, damp removal, measures of thermal efficiency, heating installation, etc.

2. Works in common elements of buildings: lift installation, roof and façade repair or change, accesses, etc.

\section{Full redevelopment of the district.}

In the first two cases, an outright grant is given to cover $50 \%$ of work costs on average -this percentage may vary in the case of works within homes between $30 \%$ and $80 \%$ depending on the home income level. The rest of the rehabilitation costs may be funded through soft loans negotiated by local authorities with a financial institution. In the third case, the State funds $100 \%$ of redevelopment and social and environmental costs of the whole district.

Obviously, the granting of an ARI and the integrated rehabilitation intervention in a district immediately involves a considerable increase in the value of its housing. That is why the process must be under permanent public control with mechanisms to safeguard those social interventions prohibition to sell for a certain number of years, preventing eventual speculators from buying homes before works are started, etc.

The ARI intervention instrument was created having in mind many districts in Spain that were built during the time of "development policies" along Franco's dictatorship -50's to 70's-, when Spanish society underwent a rapid industrialization and tertiarization, particularly in big cities, which forced the authorities to intervene urgently in housing building for lower classes due to housing shortage and the risk of mass building of substandard housing and problems of social exclusion because many social groups could not afford to buy a house [21]

This kind of intervention involved a type of building promoted and carried out entirely by the administration, always with a social purpose [22]. This was usually well planned housing estate with an appropriate town planning, providing the district with all the necessary services and leisure green areas, though normally away from urban centres and having some intra-urban communications problems. However, city growth has given this greater appeal due to speculation. In addition, many other privately promoted districts appeared in this period to receive the mass migration of people from the countryside to cities. Now such districts have the same degradation problems, mainly arising from low-quality building material as well as from previous and existing social degradation and exclusion problems - low-income levels, ageing, drug addiction, neglect and deterioration of common areas, little or no maintenance of buildings and dwellings, etc. In other words a new class of sub-standard housing has emerged.

We believe, therefore, that ARIs are an essential instrument to include in future LA21s, as it considers the same fundamental premises of sustainable development integration of the concepts of development, social wellbeing and quality of life-, demands an equal distribution of wealth and puts forward a rational use of resources as a condition to achieve long-term territorial habitability.

Moreover, the philosophy of the declaration of ARI is linked to another of the main issues set out in LA21s implementation, citizens' participation throughout the process, a fundamental aspect as residents of derelict districts eligible for financial aid for rehabilitation must have their say and participate by pointing out the deficiencies of their homes and residential areas, the virtues of their districts, their aspirations and those aspects needing intervention to improve their quality of life (Fig. 3).

In order to be declared an ARI area, town councils must apply to the relevant regional government, which has to verify that all the necessary requirements are met to grant such declaration. If the government of the Autonomous Community -regional government- gives its approval, the central government declares the ARI area and provides it with the funds needed for the actions to be carried out. The town council must submit a report proving the need of action by means of an analysis of the physical, social and environmental degradation process of the district, the ageing level, existing social and economic problems, neglect of economic activities, etc., as well as an exact demarcation of the district and an assessment of the number of dwellings needing intervention. What is new about this policy is that town councils must have studies to demonstrate the need to implement rehabilitation measures and how to integrate them in already existing LA21s or in LA21s which are being implemented.

Many town councils in Galicia, together with others in Catalonia, Madrid and Castille-León have been pioneers in applying for ARI areas. The advantages of this Plan and the opportunity it offers, the social and architectural recovery of degraded districts, have caused applications to shoot up and exceed the initial forecasts: 170.000 dwellings have been rehabilitated during the four-year period. In only a year and a half -from mid-2005 to January 2007-, 124.635 rehabilitation actions had already been financed $-73 \%$ of the Plan-, so that now it is being considered to extend the funding to exceed the initially planned number of dwellings.

$\mathrm{We}$, as social researchers, have been fortunate enough to be hired by Santiago's town council to draw up the programme report to apply for the first ARI area in Galicia Vista Alegre district. The report- was granted with express congratulations by the government of the Autonomous Community on the its quality and acceptability. Its methodology was immediately used by other researchers to draw up reports justifying the need to put into effect the 37 applied and/or granted ARIs in the beginning of 2007 March- in this Autonomous Community. Fig. (4) shows an 


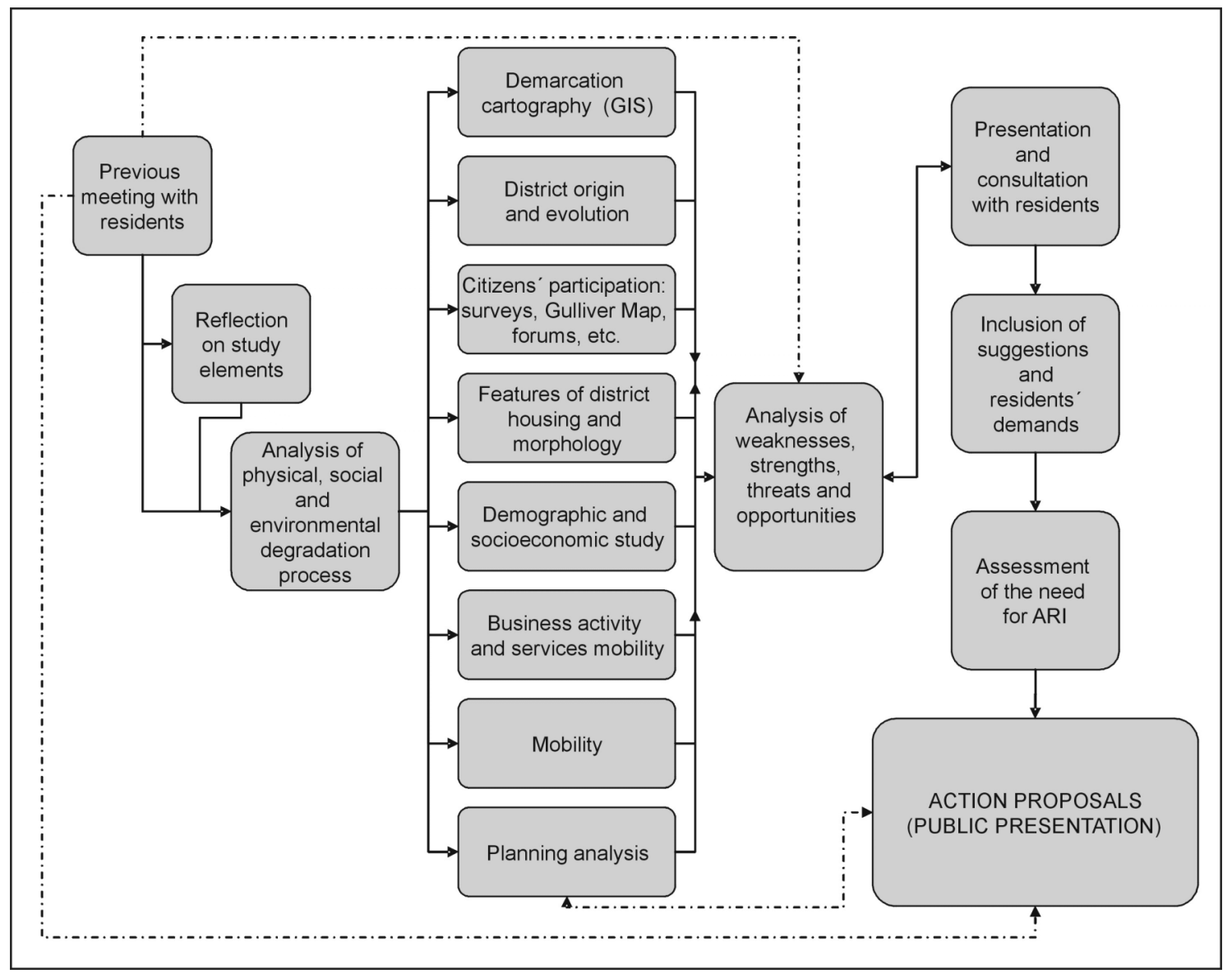

Fig. (3). Method to Study the Need to Introduce an ARI Area. Source: [23].

overview of the most significative part of the Vista Alegre neighborhood.

This methodology -which can be easily integrated into LA21s is shown in the above chart, where it can be seen that citizens' involvement is essential in the process before starting to work to find out neighbours' concerns and the social atmosphere of the district, in the intermediate process -doing surveys to ask for their needs, perceptions and aspirations regarding the rehabilitating intervention-, and in the presentation and consultation prior to working out final conclusions and action proposals.

\section{CONCLUSION}

The process of the introduction of Local Agendas 21 in Spain, though late, has gained great impetus in recent years. Many town councils have begun to apply this methodology, which aims at achieving sustainable development in three dimensions: the economy, the society and the environment.

From a critical point of view, it is necessary to argue that some municipalities join the Local Agenda 21 in Spain as a question of urban marketing. The massive adhesion to these kinds of programs can be explained by a need to imitate other municipalities, in which the Local Agenda 21 has been implemented more or less successfully. But sometimes the new municipalities joining these programs do not have the human resources or the real will to develop the LA21 properly. The possibility of getting funding and to been presented as "sustainables" is often a good reason to join.
Bearing in mind these facts, although the LA21 is a very consistent and valid tool from a theoretical point of view, its practical implementation poses numerous problems. We the difficulty of achieving real citizen participation involving all social stakeholders and the whole population. This is particularly so in the case of Spain, a country where the sociological inheritance of Franco's regime is still visible in the lack of bottom-up policies, especially compared to other European northern countries, where they are more common Sweden, Germany, the UK, etc.

This difficulty of implementing LA21s by means of real citizens' participation processes, together with the fact that many town councils join an LA21 in a symbolic way to receive a "clean-up", explain the presence of a lot of criticism in Spain. In spite of this, there are cases of good practices that are worth highlighting. In this essay we have focused on two main aspects fully related to the implementation process of LA21s: sustainable mobility and recovery of degraded urban areas.

As to the first aspect, we should emphasize the existence of a group of cities with a deep historic tradition where a systematic mobility planning can be observed. Santiago de Compostela, Oviedo, Granada and Toledo stand out among them, as they have been able to face the challenges posed by the coexistence of tradition and modernity -pedestrian mobility and traffic. Mobility management is nowadays recognized as one of the most effective ways to fight for urban sustainability. These practices include the promotion 


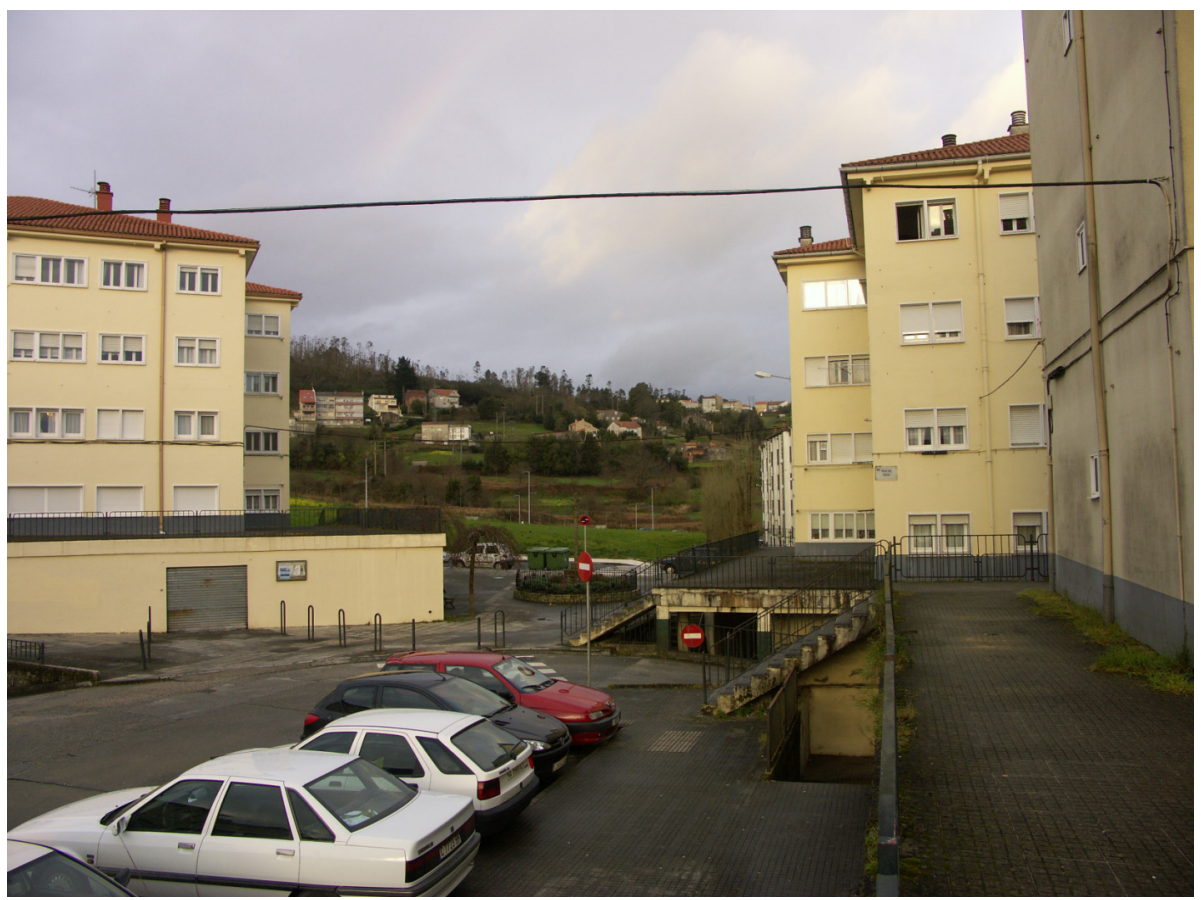

Fig. (4). The Vista Alegre District before the Implementation of the ARIs. Source: Self-Made.

of public transport and the creation of networks of pedestrian itineraries, connecting the main points generating and attracting mobility in the city.

As to the second aspect, we have demonstrated the efforts being made by the Spanish administration to revitalize those parts of the fabric of our cities which are in increasingly deteriorated condition. Recovering districts and providing their residents with a better standard of quality of life is equivalent to slowing down the sprawl of our cities and limiting its economic, social and environmental impacts.

This program has to be implemented bearing in mind the physical, the economic and the social dimension. The recovering of these residential areas has to focus on the three dimensions of sustainability.

For the process of drawing up reports prior to the grant of an Area of Integrated Rehabilitation required to town councils in Spain, geographers have a lot to contribute, as successfully proved in Santiago de Compostela. It is especially interesting the role of the geographer as a coordinator in the socio-demographic analysis (sociodemographic features, familiar structures, attitudes and perception), prior to the implementation of the works of the ARIs. By using surveys and interviews, the geographer draws the general perception of the local population on the application of these measures. Very often happens that local residents are very receptive to the rehabilitation, since they appreciate the possibility of improving their quality of life, conserving the sense of place.

\section{REFERENCES}

[1] Brunet J, Almeida F, Coll M. Agenda 21: Subsidiariedad y cooperación a favor del desarrollo territorial sostenible. In: Boletín de la Asociación de Geógrafos Españoles 2005; 39: 423-46.

[2] Martínez VJ, Martín LMA. Agenda 21 locales como instrumento de ordenación territorial: la Mancha Alta Conquense. Estudios Geográficos 2002; LXIII(248/249): 711-31.
[3] Aguado MI, Echebarría MC. Medio ambiente y desarrollo sostenible en España. Boletín Económico del ICE 2003; 2786: 2130 .

[4] Font N. Local y sostenible. In: Font N, Subirats J, Eds. Local y sostenible. La Agenda 21 Local en España. Barcelona: Icaria 2000; pp. 9-28.

[5] Hewit N. European Local Agenda 21 Planning Guide. How to engage in long-term environmental action planning towards sustainability? Friburg: ICLEI 1995.

[6] Gomila MF. La Agenda 21 Local en Europa: un análisis comparado. In: Font N, Subirats J, Eds. Local y sostenible. La Agenda 21 Local en España. Barcelona: Icaria 2000; pp. 29-64.

[7] Manuel D, Martí N. La Agenda 21 Local en Cataluña. In: Font N, Subirats J, Eds. Local y sostenible. La Agenda 21 Local en España. Barcelona: Icaria 2000; pp. 137-68.

[8] EPOMM 2007. European Platform on Mobility Management 2007. Available from: http://www.epomm.org

[9] Pozueta EJ. Movilidad y planeamiento sostenible: hacia una consideración inteligente del transporte y la movilidad en el diseño urbano. In Cuadernos de Investigación Urbanística 2000; 30: 1109.

[10] Crawford JH. Carefree cities. International books 2002.

[11] Sanz AA. Transporte en modos no motorizados. Ciudad y territorio 1980; 2: 93-110.

[12] Sanz AA. Calmar el tráfico, domesticar el automóvil. In: Ciudad y territorio: Estudios territoriales 1994; 100-101: 397-409.

[13] Gutiérrez J. Transporte, movilidad y turismo en los centros históricos. Ería 1998; 47: 241-48.

[14] Santiago De Compostela's Town Council Plano Integral de Mobilidade. Unpublished. Santiago de Compostela 1992.

[15] Monheim R. Pedestrian precincts in German city centres [Fussgangerbereiche in deutschen innenstadten]. Geographische Rundschau 2000; 52(7-8): 40-6.

[16] Sanz Alduán A. Movilidad y sostenibilidad: un escollo para la sostenibilidad urbana [Ciudades para un futuro más sostenible, 1997]. Available from: http://habitat.aq.upm.es/cs/p3/a013.html

[17] Campos RML. Movilidad y preservación ambiental en las ciudades Patrimonio: el ejemplo de Toledo. In: Castillo MA, Ed. Ciudades Históricas: conservación y desarrollo. Madrid: Fundación Argentaria y Visor 2003; pp. 35-44.

[18] Troitiño VMA. Cascos antiguos y centros históricos: problemas, políticas y dinámicas urbanas. Madrid: MOPT 1992.

[19] Campesino FAJ. Gestión equilibrada del turismo cultural: su aplicación a Granada. In: Desarrollo turístico integral de Ciudades 
Monumentales. Granada: Patronato Provincial de Turismo de Granada 2003; pp. 599-616.

[20] Spain's Housing Ministry: Plan de Vivienda 2005-2008. Available from: http://www.mviv.es/es/pdf/normativa/BOE130705.pdf

[21] Brandís GD. El paisaje residencial de Madrid. Madrid: Ministerio de Obras Públicas y Urbanismo 1983.
[22] Terán F. Historia del Urbanismo en España. Siglos XIX y XX. Madrid: Cátedra, 1999

[23] Aldrey VJA. A rehabilitación integral de barrios degradados fóra dos ámbitos dos cascos históricos: metodoloxía de análise na Memoria-programa das ARI. Xeográfica 2007; 7: 5-26.

(C) Vázquez and Otón; Licensee Bentham Open.

This is an open access article licensed under the terms of the Creative Commons Attribution Non-Commercial License (http://creativecommons.org/licenses/by$\mathrm{nc} / 3.0 /$ ) which permits unrestricted, non-commercial use, distribution and reproduction in any medium, provided the work is properly cited. 